\title{
ON THE FUTURE IMPLEMENTATION OF SCHOOL DESEGREGATION: SOME CONSIDERATIONS
}

\author{
WiLLIS D. HaWLEY* \\ RAY C. RIST ${ }^{\dagger}$ \\ INTRODUCTION
}

When public officials act so as to maintain or increase racial separation in schools, they are denying students equal protection of the laws. But the greater difficulty is not in determining that the Constitution has been violated, but in devising a remedy accessible and acceptable to both the courts and policy makers. The situation is further complicated when school segregation is not directly attributable to actions of public officials, but comes about because of segregated housing.

The remedies for school segregation seemed readily apparent, so long as we believed that racial segregation, regardless of its cause, resulted in harm to those segregated and that desegregation would diminish or eradicate such harm. The present mood is one of less certainty. There is growing doubt that the hopes many have had for the outcomes of school desegregation can be fully achieved. This is particularly true for those who have looked to desegregation to overcome the persistent academic disparities between the average performance of white students and that of minority students. Desegregation does not appear to be the panacea many hoped it would be.

This uncertainty has led to an apparent increase of the ranks of those who argue that the time has come for the courts and policy makers to weigh the advantages of school desegregation against the costs. ${ }^{1}$ Heretofore, the emphasis has been strongly on the benefits which were to accrue, while the costs of such social change have received only minimal attention, or have been ignored altogether. There is now a growing recognition that the costs as well as benefits must be calculated and that a range of values for both whites and nonwhites must be considered in the equation, if school desegregation is to occur in a

\footnotetext{
* Associate Director. Institute for Policy Sciences and Public Affairs and Associate Professor of Policy Sciences and Political Science, Duke University.

† Head. Desegregation Studies Unit, National Institute of Education, Department of Health. Education, and Welfare.

The authors, in preparing this paper, have relied heavily on the work of Flizaberh Cohen, Edgar Epps, and Meyer Weinberg published in this present issue of Law and Contemporary Problems. The second author wishes to note that the comments and conclusions in this article are solely his own and no endorsement or support from the National Institute of Education and the Department of Health, Education and welfare is intended or should be inferred.

I. Cf. Fiss, The Jurisprudence of Busing, 39 Law \& Contemp. Prob. no. 1, at 194 (1975).
} 
manner that recognizes the integrity of the students and the need for sound educational programs.

If we are to achieve any of the several objectives that school desegregation is meant to achieve, we will have to abandon the simplistic notion-now largely discredited by available evidence-that the mixing of races in itself will invariably have positive educational and social consequences. While this argument may seem obvious to those who have been involved in the desegregation controversy, its implications are not well understood. For to accept this argument means that in many situations, conventional court orders which result only in achieving greater racial balance by reassigning pupils will not be enough, even if coupled with such admonitions as the need for retraining of teachers and school administrators and for the provision of special programs during periods of transition. Moreover, if we accept the notion that the consequences of school desegregation must be considered in each case, not only will the job of the courts be complicated, but we will have to consider such broader issues-forced upon us by recent evidence-as the impact of school desegregation on the racial composition of cities. ${ }^{2}$

We are not suggesting that the presumption in favor of desegregated schools should not persist or that legal findings of segregation should not be cause for new public policies or a continuation of legal action. But we would not stop there. We argue that establishing the existence of segregated schools would trigger certain inquiries to determine what combination of strategies would be most likely to achieve a set of specified social and educational objectives. We argue that policies which foster desegregation without taking into account how local contexts shape the likelihood that alternative strategies will maximize the benefits minorities will receive, have the effect of denying equal educational opportunity. The issue is not whether actions by public officials which maintain or foster racial segregation in the schools should be tolerated. Such actions are clearly unconstitutional and are no longer debatable. Similarly, the issue whether we should, as a matter of national commitment and public policy, move toward the goal of integrated classrooms is no longer debatable. Rather, the issue is how the goal of increasing integration can best be attained.

\section{Achieving the Goals of Desegregation}

Before one can develop a strategy for maximizing the probability that school desegregation will have positive consequences for children, one must be explicit about the goals one wants to achieve. If the goal is desegregation per se then the strategy is relatively simple-secure a reasonably proportional dis-

2. See Farley, Racial Integration in the Public Schools, 1967-1972: Assessing the Effect of Governmental Policy, 8 Sociological. Focus 1 (1975). 
tribution of whites and nonwhites in each of the district's schools. But few of us really favor school desegregation for its own sake. Rather, we desire desegregation because of the impact we believe it has on children. It is important to judge desegregation as one would judge any other social policy: whether and to what extent it achieves certain valued ends. These values, of course, may be instrumental, symbolic, or they may be "first order" principles such as equal protection of the laws. Seeing school desegregation as a process rather than as an outcome with its own justification has important implications for the way we proceed to determine the criteria which govern the assignment of students to schools. Thus, for example, "racial balance" alone would seldom be a sufficient factor on which to base a desegregation plan.

We seek here to identify some considerations that would increase the probabilities that certain specified educational and social objectives will be achieved through desegregation. This article is not a definitive summary of the empirical evidence on the effects of desegregation but it does draw heavily from the research literature in an effort to encourage more flexibility and imagination among those who integrate the schools, whether they be judges, lawyers, school officials, or consultants charged with drawing up desegregation plans.

Those who turn to social science literature for information on the consequences of desegregation are faced with numerous problems including: considerable controversy over appropriate methodologies and levels of analysis; varying definitions of critical variables such as "desegregation" and "student achievement"; and contradictory conclusions which frequently are not harmonious with or are overstatements of the empirical evidence. ${ }^{3}$ But perhaps the most important problem is that theories of cause and effect often do not underlie the analyses, and the data collected are seldom utilized to test or formulate such theories. ${ }^{4}$ Thus, in this article, our basic analysis will be in the context of the theoretical assumptions which underlie the idea that desegregation can lead to the attainment of certain goals. ${ }^{5}$

The goals to which the advocates of desegregation aspire are of four general types:

(1) improvements in self-esteem, aspirations and other personality related dispositions of minority children;

(2) improvements in academic achievement;

3. As one federal district court judge has said. "much of the current research replies to precise policy based questions with the ambiguity of a Delphic oracle . . " Hart 1 . Community School Bd.. 383 F. Supp. 699.744 (E.D.N.Y. 1974).

4. For one effort to develop a comprehensive theory of the effects of school desegregation that could guide future research, see Rand Corporation. Design for a National. Longitudinal Study of School Drsegreation (1974).

5 . We are dealing here with what Alvin Gouldner, in a slighty different context, hats comed the "domain assumptions" which undergird a theoretical formulation but which are frequently left implicit. Se" gemerally. A. Golidxr. The Coming Corsis of Westers Sociology (1970). 
(3) reduction in interracial hostility and the elimination of racial intolerance; and

(4) increased access to educational resources and to post-education opportunities.

This article examines both the theory and the research concerning each of these goals and how they might be secured.

\section{A. Psychological Consequences of School Desegregation}

In Brown v. Board of Education, which in 1954 outlawed segregation in the public schools, the Supreme Court, speaking unanimously through Chief Justice Earl Warren, focused attention on the psychological impact of racial separation: ${ }^{6}$

To separate [Negroes] from others of similar age and qualifications solely because of their race generates a feeling of inferiority as 10 their status in the community that may affect their hearts and minds in a way unlikely ever to be undone.

The social science evidence which the Court cited in support of this contention ${ }^{7}$ was not strong but it seemed to make intuitive sense, especially when one considered the history of treatment of blacks by whites and the reasons schools were legally segregated by race in the first place. Whatever validity the stigma theory had in the 1950's, the events of the last two decades could be seen as undermining its. logic. With segregation of all types now outlawed, the civil rights movement launched, and the racial pride of minorities enhanced through the actions of minority organizations, the argument that school desegregation is necessary to reduce psychological damage to blacks, which appears to some to be a quasi-racist position itself.

A number of researchers have sought to verify the "psychological damage" theory. However, this research is plagued with all of the problems that attend most research on desegregation-such as inadequate controls, inadequate definitions, and inadequate specification of conditions that characterize the learning environment. And the problems of drawing generalizations from this research are compounded by the multiplicity of measures researchers have used to assess the attitudes and personality characteristics of children and by the fact that most of these measures have not been validated.

When all of the available research is considered, two conclusions can be made: ${ }^{8}$

6. Brown v. Board of Educ., 347 U.S. 483, 494 (1954).

7. 347 U.S. at 494-95 n. 11.

8. For reviews of the research upon which these generalizations are founded, see N. ST. JOHN. School Desegregation Outcomes for Children (1975); Epps, The Impact of School Desegregation on Aspirations, Self-Concepts and Other Aspects of Personality, 39 Law \&. ConteMp. Prob. no. 2, at 300 (1975). 
(1) blacks do not have lower self-esteem or aspirations than whites, when socioeconomic status is controlled; and

(2) when desegregation has been found to affect either self-esteem or aspirations, the effects are mixed at best.

The negative consequences of desegregation for self-esteem and sense of anxiety about school seem most likely to occur when minorities are placed in overwhelmingly white classrooms where competition for grades is intense and the racial minority is, at the time of desegregation, performing substantially below the classroom average. As might be expected, the effects of these conditions are likely to be greatest among older children.

The supportive role of teachers and the organization of the classroom appear to be significant factors both in minimizing invidious comparisons by whites of the lower performance of less well prepared classmates, and in providing a sense of achievement in terms of the base from which each individual student must work. ${ }^{9}$ And the role of the principal in fostering pro-integration behavior by teachers has been found to be of significant importance. ${ }^{10}$

Thus in order to make an argument for using school desegregation to enhance the self-esteem and aspirations of minorities, one or more of three concomitant outcomes would be necessary:

(1) Improved academic achievement,

(2) improved race relations,

(3) increased opportunities to utilize one's talents both inside and outside of school settings.

It follows then that improvements in self-image may be seen as the products of the attainment of other objectives of school desegregation. Of course, students with self-confidence and with high aspirations are more likely to achieve at higher levels and to be less defensive in social relationships. But racial mixing in itself seems to hold little promise of directly increasing self-esteem and other aspects of psychological development.

\section{B. The Effect of Desegregation on Academic Achievement}

If increases in academic achievement can lead to increased self-confidence which in turn can lead to higher achievement, can desegregation increase the academic achievement of minorities? There is good reason to believe that (1) in most cases where nonwhites are in the minority, the academic performance of whites is unaffected by desegregation and (2) the performance of blacks-in

9. Cf. R. Rist, Black Kids, White Realities: A Study of School Integration (forthcoming $1975)$.

10. Narot, Teacher Prejudice and Teacher Behavior in Desegregated Schools, in 2 National. OpINion Research Center, Southern Schools: An Evaluation of the Effects of the Emergency School Assistance Program and of School Desegregation (1973) phereinafter cited as Southern Schools]; Orfield, How to Make Desegregation Work: The Adaptation of Schools to Their Newly-Integrated Student Bodies, 39 LAw \& Contemp. Prob. no. 2, at 314, 322-24 (1975). 
most cases-is not negatively affected by desegregation. However, evidence concerning the positive effects of desegregation on minority achievement is mixed and inconclusive. ${ }^{11}$ There is some agreement among scholars who have done large-scale studies of the impact of desegregation that nonwhites-or at least blacks-do best academically in integrated settings where they are neither in the substantial majority nor in a minority of less than 10 to 20 per cent of the student body. ${ }^{12}$

In general, the studies show that black children going to school in majority white settings do better than black children in segregated schools. But the reasons for this finding are not clear. There is a considerable amount of research that shows that family background is a good predictor of student performance in school and that such surrogates for background as socioeconomic class account for substantially more of the variance in student performance than either race or the racial mix of the school or classroom. It is possible, indeed likely, that where desegregation involved voluntary enrollment by blacks in predominantly white schools, the positive effects resulting from desegregation are largely due to the mixing of students from different backgrounds. Some researchers have tried to "control" for family background in their analyses, but the control measures most commonly used-such as socioeconomic class-are only gross measures of those student experiences at home which are relevant to their attitudes, behavior, and capacity in school.

Given these problems in obtaining a definitive answer from the research on the effects of desegregation on achievement, it is necessary to examine the theoretical assumptions which might underlie the notion that a cause-effect relationship exists between desegregation (or integration) and educational attainment. It is sometimes inferred that blacks will do better when they attend school with whites because the latter act as role models. That individual blacks should emulate individual whites only because they are white seems unlikely. Blacks who are low achievers may use high achieving whites as models but two conditions must first be met: (1) racial hostility must be low, and (2) the dominant norms of the school or, more importantly, the classroom must be supportive of attitudes and behavior which encourage academic achievement. If these two conditions are necessary for the role model thesis to work, then that thesis needs reformulation.

An alternative theoretical assumption is that the achievement levels of blacks will increase following desegregation because the group norms in predominantly white schools are more supportive of higher achievement than those in predominantly black schools. But the difficulty with this premise is that

11. See N. ST. JohN, supra note 8 , at $36,119$.

12. The most recent study to report the finding is Jencks \& Brown, The Effects of Desegregation on Student Achievement: Some New Evidence From the Equality of Educational Opportunity Survey, 48 Sociology of ED. 126 (1975). 
it rests on the untenable proposition that skin color itself predicts the value placed on achievement.

A third and perhaps more intuitively believable hypothesis is that differences in family background, rather than the race of students, account for any variations that might be found in the emphasis placed by blacks and whites on achievement in school. In other words, families differ in the degree to which they stress the importance of working hard in school and in their capacity to provide reinforcement at home in the form of time, educational background, and resources. This "backup" capacity is related to a family's socioeconomic position. Wealth, occupation, and prior education all tend to be associated with a commitment to high academic performance. Thus the idea that minority children benefit from attending desegregated schools because their peers have values reinforcing cognitive learning is more an argument for social class integration than for racial integration. ${ }^{13}$ The peer-group-norm hypothesis is most credible when desegregation occurs at the classroom level where the norms will be most unambiguous and enforceable.

Given that the racial minorities in the United States are disproportionately poor, racial desegregation can often result in increasing the socioeconomic heterogeneity of schools. Nevertheless, insofar as one expects to increase the achievement of minorities because of the peer group norms existing in desegregated schools, attention to racial mix is an imperfect and inadequate strategy. While racial minorities may often be low-income, so may the whites with whom they are integrated.

A fourth explanation for the increases in the academic achievement of minority students that are hypothesized as resulting from desegregation is the stigma theory discussed previously. Segregation, the argument goes, leads to low self-confidence and low aspirations. Yet as we noted earlier, the evidence that segregation leads to low self-esteem and feelings of hopelessness is at best inconclusive and is probably more supportive of the argument that differences in aspirations and self-esteem between blacks and whites are negligible, when social class is controlled. The evidence is also inconclusive with respect to desegregation and its impact on aspirations and self-esteem.

Blacks and other nonwhites might perform better in desegregated schools, a fifth explanation goes, because teachers in such schools expect more academically; that is, the norms found in the classroom are reinforced by the teacher demanding high performance. Why teacher expectations for blacks are higher in predominantly white schools than in predominantly black ones, if indeed they are, is not clear. Logic suggests that to the extent this phenomenon is true it should have little to do with race itself, although there is no question that

13. A substantial body of literature supports this theory. Sep U.S. Commission on Civil Rights, Racial Isolation in the Public Schools (1967); N. St. John, supra note 8; J. Coleman, Equality of Educational Opportunity (1966); C. Jencks, Inequality (1972). 
teacher expectations often play an important role in the achievement levels attained by children, particularly with younger children. ${ }^{14}$

A final hypothesis concerning the relationship between higher academic performance minorities and school desegregation is that predominantly white schools tend to have better facilities, greater resources, and-perhaps because they can pay more-better teachers. The Coleman Report has thrown some doubt on the importance of school facilities and per capita expenditures to improved student performance. ${ }^{15}$ Other studies, however, show that the level of school resources is an important factor in raising achievement levels. ${ }^{16}$ In any case, equity in school resources is not necessarily related to racial composition. Thus if desegregation is to be justified because it makes the resources money can buy more accessible to minorities, evidence that this will occur should be part of the criteria employed in drawing desegregation plans.

The foregoing examination of theoretical assumptions as to why, if at all, racial desegregation should lead to improved academic performance of nonwhite children suggests that desegregation plans should go beyond the criterion of black-white ratios and move to other considerations. ${ }^{17}$ Among those considerations, the following appear most salient:

(1) The socioeconomic status of the majority of students in a school and within classrooms after desegregation; ${ }^{18}$

(2) the amount of school resources in those schools to which minorities are moved compared to the resources available in schools which are predominantly nonwhite;

(3) the extent to which explicit or tacit racism by teachers in desegregating schools can be mitigated; 19 and

(4) the extent to which racial tolerance can be maximized and racial stereotypes among classmates can be eliminated.

\section{The Effect of School Desegregation on Race Relations}

We have argued that good race relations in schools are likely to promote academic achievement. Since racial tolerance reduces the likelihood of defensiveness and invidious comparisons across racial lines, it seems likely that desegregation will contribute to the development of strong egos and positive

14. Cf. Rist, Student Social Class and Teacher Expectations: The Self Fulfilling Prophecy in Ghetto Education, 40 Harv. ED. Rev. 411 (1970).

15. J. Coleman, supra note 13, at 312-16.

16. J. Guthrie, G. Kleindorfer, H. Levin \& R. Stout, Schools and Inequality (1971). See also 1 Southern Schools 99.

17. See N. ST. John, supra note 8, at 36-38; Jencks \& Brown, supra note 12, at 137-40. Contra, 2 SOUTHERN SChOOLS 80.

18. Other measures of family background and family disposition toward learning are needed, but social class is the most readily determined and widely agreed upon surrogate at the present.

19. Orfield, supra note 10 . 
attitudes toward school. But does school desegregation lead to improved race relations and, if so, why?

As with other areas of research on the effects of school desegregation, the evidence here is inconsistent and mixed. And since most of the research has been carried out without any firm hypotheses or theory on which to ground the research design, it is difficult to eliminate the ambiguity of the research findings. ${ }^{20}$ Indeed, researchers seem to differ as to what a positive finding is. For example, is preference for friends of one's own race-especially with regard to the minority students - a sign of racial pride or of interracial hostility? Identity with one's own race does not necessarily lead to intolerance of other races, but not enough studies give us the kinds of data needed to uncover the interrelation of these two sets of attitudes.

Perhaps the most serious shortcoming of studies dealing with the effects of desegregation on race relations is that very few of them involve longitudinal research. ${ }^{21}$ Attitudes toward persons of another race, especially where older children are involved, on theoretical grounds would be expected to reflect the values and attitudes of their families and their neighborhood peers. To expect that desegregation would have a considerable short-run impact in altering negative racial dispositions is unrealistic. Thus, in a very important sense, we have not yet really begun to test the effects that mixing the races in school might have on racial attitudes.

Nevertheless, the current research findings, as ambiguous as they are, should not be totally dismissed, as there is the possibility that the data now available can provide guidelines to enhance the probability that desegregation will lead to greater racial understanding. Differences in methodology and research design do not completely account for the variations among the studies in the findings. ${ }^{22}$ If this is so, we need to search the data for evidence that the conditions under which racial mixing occurred in the schools studied might account for the apparent confusion. It is essential, however, that any conclusions one might draw from this approach-however tentative one claims them to be-make theoretical sense.

We believe that the available evidence does allow one to say that in the short run the mixing of races by itself is, at best, likely to have no positive effect on racial attitudes of either whites or nonwhites, and that the results may be more negative than positive. ${ }^{23}$ This latter case is especially true in communities where

20. For a detailed attack on the theoretical character of research in this field, see Cohen, The Effects of Desegregation on Race Relations, 39 LAw \& Contemp. Prob. no. 2, at 271 (1975).

21. Longitudinal studies are those which include at least two sets of data gathered over a period of time. Generally what is being measured is the change in a particular characteristic or phenomenon over time. Cross-sectional studies, on the other hand, are those based on data collected at one point in time. Relationships are static between people or groups or whatever is being studied at that point in time.

22. N. ST. JoHN, supra note 8 , at $71-80$.

23. Such are the findings of the recent controversial study by David Armor. Armor, The Evi- 
desegregation is unpopular and contested by a substantial segment of the community. On the other hand, the data, when coupled with a theoretical understanding of the process by which prejudice and stereotypes are reduced, do allow one to specify some conditions which will increase the likelihood that desegregation will result in better race relations.

A dominant theoretical formulation of the conditions which foster the breakdown of prejudice and racial stereotypes was first formulated by Gordon Allport. ${ }^{24}$ This perspective, as elaborated by scholars such as Thomas Pettigrew $^{25}$ and Elizabeth Cohen, ${ }^{26}$ holds that the chances that school desegregation will improve race relations are greatest when the following conditions exist: (1) contact continues over a period of time, (2) the parties involved are of "equal status" and share common goals, and (3) racial interaction is approved and supported by those whom both races accept as authoritative. Let us examine each of these briefly.

\section{Continuous Long Run Contact}

The period of time necessary for school desegregation to "take" is not ascertainable from existing research. However, much of the research suggests that an increase in interracial understanding is more often the product of desegregation when young rather than middle school or high school children are involved. Moreover, the importance of classroom desegregation which fosters interracial interaction-what some prefer to consider "real integration"-is given additional support by this condition of Allport's theory. A recent major study of southern schools also shows that the longer students attend integrated schools the more positive they are toward other races. ${ }^{27}$ This evidence suggests that to anticipate overnight improvement in race relations as a result of racial mixing in schools is unreasonable.

\footnotetext{
dence on Busing, 28 PuB. INTEREST 90 (Summer 1972). Though Armor's study of busing conflicts with other research, and though it has been subject to considerable criticism, it is not difficult to believe the conclusions he reaches with respect to the alienation and intolerance of whites that minority children attending overwhelmingly white schools feel. In the cities studied, nonwhites were bused-often fairly long distances-to schools where teachers and principals had little experience with nonwhite or poor children and where programs did not take into account differences in formal background. Moreover, these nonwhite children often returned home after school in the suburbs to fight their way back into neighborhood peer groups in which most children attended the same schools in central cities where nonwhites tended to possess racial self-consciousness and to advocate aggressive political action in the pursuit of the interests of minorities. This situation dramatizes the potential danger of so-called "token integration" in which small numbers of nonwhite siudents in a sense "represent" their race in white schools. But it also indicates that a finding that token integration has failed, especially in the kinds of situations Armor studied, is hardly a fair test of the probable effectiveness of desegregation in the long run.

24. G. Allport, The Nature of Prejudice (1954).

25. T. Pettigrew, Racially Separate or Together (1971)

26. Cohen, supra note 20.

27. I Southern Schools 53.
} 


\section{Equal Status Cooperative Contact}

Scholars differ on what "equal status" entails. Present research findings do support the notion that desegregation most often results in improved race relations when it involves students of similar social class background. Ability grouping which results in resegregation within the school or classroom would certainly not promote the reduction of racial stereotypes, but then neither would conditions which force students who are less well prepared to compete with those who achieve at a substantially higher level. The impact of ability grouping is a complicated matter and seems to depend on the age and differences in achievement levels of the children involved. There is considerable agreement that ability grouping among elementary children is dysfunctional both in terms of achievement and improving race relations. ${ }^{28}$ But as children get older, peers become more salient to their identity and the gap in achievement levels tends to widen. Then ability grouping in certain courses, especially when it involves the self-selection of students, may reduce anxiety among low achievers and foster more favorable interracial attitudes. ${ }^{29}$ When correlations between race and achievement levels mean that interracial contact is minimized by ability grouping in certain high school classes, interracial contact will necessarily need to be encouraged in other classes and in other settings before school desegregation can result in improved racial attitudes.

Some educators believe that schools that are competitive and teachercentered are not good environments in which to foster racial understanding. They urge schools to deemphasize such visible incentives as grades, to increase the use of individualized and multi-aged instructional strategies, and to seek out ways to promote positive interaction among children of different races. The latter goal is based on the recognition that if students have different strengths, conditions of "equal status" will occur when reciprocal dependencies between races on a variety of activities that are valued by the teacher and by other students are developed. ${ }^{30}$ On the other hand, if teachers respond to the initial classroom disorder that often accompanies the introduction of children with different habits and expectations to new settings by employing more traditional and discipline oriented methods of instruction and classroom management, the possibilities of improving race relations may be greatly diminished. ${ }^{31}$

\section{Support From Authority}

There is every reason to believe that a crucial variable affecting the impact of desegregation on race relations is the role played by teachers and adminis-

28. Orfield, supra note 10 , at 326.

29. Id. at 326-27. See also 1 Southern Schools 62, 83.

30. See Cohen, supra note 20, at 278-81.

31. Cf. N. St. John \& R. Lewis, Children's Interracial Friendships: An Exploration of the Contact Hypothesis, 1973 (unpublished paper at the University of Massachusetts); R. Rist, supra note 9 . 
trators. Where teachers and school officials aggressively seek to improve race relations, establish norms, and deal with problems so as to create an environment that at the least discourages the expression of racial hostility, and at best creates a spirit of commitment to interracial harmony, the impact on race relations is substantial. As St. John has noted: ${ }^{32}$

Administrative sanction is probably the most important precondition of prejudice-reducing contact in schools. If central office staff is determined that integration shall be complete, the status of all children made equal, and racial competition avoided, the other necessary ingredients of healthy biracial schools probably will follow.

Likewise, in his assessment of the desegregation programs in a number of California schools, Wirt has observed: ${ }^{33}$

[That] principals appear in about every desegregating system who make a difference to the education of minorities, who bring all constituencies into their planning and implementation, and who produce an educational environment that literally bubbles with the excitement of learning.

\section{Equal Access to School Resources and Opportunities for Post-School Success}

We have already noted that the process of desegregation does not appear to have any necessary relationship to changes in the quality of school facilities and personnel that children of either race are likely to experience. Therefore, if the objective for desegregating schools is to assure equality of access to facilities, programs, and quality teachers, it is an inefficient tool. In other words, more direct approaches to achieve redistribution of resources are available and these are more feasible politically.

To a substantial extent, the notion that life chances-the probability that one will achieve one's definition of the good life-are enhanced by school desegregation depends on the accuracy of the assumed cause and effect relationships we've already discussed and that these things-academic achievement, psychological benefits, and the reduction of prejudice-lead to success after graduation.

Henry Levin, among others, has argued that the impact schools can have on life chances has been overstated. ${ }^{34}$ It is difficult, however, to imagine that minorities would not have a greater chance of achieving their personal objectives if desegregation resulted in a reduction of racial prejudice on the part of

32. N. ST. JoHN, supra note 8 , at 98.

33. F. Wirt, Contemporary School Turbulence and Administrative Authority 24, 1974 (paper presented to Northwestern University Conference on Problems in the Governance of the Learning Community). See also Orfield, supra note 10, at 322.

34. Levin, Education, Life Chances and the Courts: The Role of Social Science Evidence, 39 LAw \& Contemp. Prob. no. 2, at 217 (1975). Perhaps the best known and most controversial discussion of this issue is in C. JENCKS, supra note 13. 
whites, an increase in the achievement levels of nonwhites, and a greater understanding by nonwhites of the values of whites. The important questions are whether schools can do these things and under what conditions they can best be achieved.

\section{Conclusion}

The issue of school desegregation is likely to be with us for years to come. Despite substantial desegregation in southern and border states in recent years, more than half of black children still attend school in majority black schools. In the North and West less than 30 per cent of black children attend majority white schools. ${ }^{35}$ Similarly in states where there is a sizable Hispano-American school population, less than half of these students attend majority white schools-and the proportion who do so is generally declining. ${ }^{36}$ That so much of the task of desegregation lies before us, coupled with the growing realization that the desegregation of schools to date has not fulfilled the expectations many have had, suggests it is time for a reconsideration of the basic and underlying assumptions influencing the present approaches. ${ }^{37}$

Such a period of reevaluation is necessary if the desegregation process is to proceed in such a manner as to maximize the probabilities that the ultimate goals of this major systemic effort at social change will be achieved. While most people sympathetic to these goals will have little quarrel with our admonition in principle, the implications may be less widely accepted. Our reconsideration of existing research suggests that when a school district is legally found to be in violation of the fourteenth amendment to the Constitution, the remedy will have to be strongly situation-specific. Thus, it might include only partial desegregation, the preservation of some one-race schools, different strategies to be adopted in different parts of the district, and the implementation of experimental programs in some schools.

Having said this, it is well to recognize that a position advocating specific solutions to local situations generates the potential for another form of controversy-that of the "fairness" of one city's treatment versus another. In short, it raises the issue of distributive justice. ${ }^{38}$ If the resolution of the school segregation situation in Atlanta is vastly different from that in Boston, or Indianapolis from Denver, doubts as to the fairness of courts or school ad-

35. Actual percentages in 1972 of blacks attending schools where more than 50 per cent of the students are white are: 46.3 in the South, 31.8 in the border states, and 28.3 in the North and West. U.S. Commission on Civil Rights, Twenty Years After Brown: Equality of Educational OpPortunity 49 (1975).

36. Id. at 52 .

37. For an excellent discussion of this point, see Cohen, Segregation, Desegregation, and Brown. 12 Society no. 1 , at 34 (1974)

38. Cf.J. Rawls, A Theory of Justice (1971) 
ministrators begin to arise. If Atlanta is allowed to retain several all-black schools, why must Boston eliminate each and every one of theirs? The moral force of the law exists only so long as those to whom it applies believe that they have been justly treated. When they come to believe they have not, the willingness to obey diminishes. There is the inverse situation as well, where one group can come to believe that it has "gotten away with something" others have not. Thus, when white parents in Atlanta become smug because they do not have to bus their own children as do the parents in Boston, the moral position of the law is undermined.

It is the authors' position that in formulating desegregation plans, greater attention should be given to meeting the educational and social needs of a particular community. The courts are beginning to move in this direction, as demonstrated by the development of a separate remedial plan by those intervening on behalf of Hispano Americans in the Denver case. This plan was accepted by the district court as appropriate to the specific problems of the Denver school district. ${ }^{39}$

Of course, more complex and differentiated strategies for achieving school desegregation will not obviate the need for busing. It seems important that the myth that busing is harmful to children be dispelled. The available evidence provides no reason to believe that busing itself-within limits broader than those contemplated by almost all desegregation planners-has negative consequences for children regardless of their race. ${ }^{40}$

While this article has discussed what desegregated schools might accomplish, it is well to remember that "a school case, like a vehicle, can carry only a limited amount of baggage." 41 Schools do not live in a vacuum apart from the rest of society or its institutions. This leads then to the further question of whether policy makers should become involved in other arenas as well to enhance the possibilities for the success of school desegregation. This would entail the development of various strategies, including litigation to assure that there is access to job opportunities, to "open housing," and to other forms of nondiscriminatory treatment over which the schools themselves have no control, but which can affect the pattern of residential segregation and hence school segregation. After Milliken $v$. Bradley, ${ }^{42}$ school integration may be impossible to achieve in many of our largest cities unless there is a concomitant move to providing minorities with greater access to housing and jobs in the suburbs.

The manner in which to proceed with school desegregation is surely not a no-win situation. There continue to be options for courts and policy makers

39. Keyes v. School Dist. No. 1, 380 F. Supp. 673, 695-96 (D.C. Colo. 1974).

40. Cf. Weinberg, The Relationship Between School Desegregation and Academic Achievement: A Review of the Research, 39 LAw \& Contemp. Prob. no. 2, at 240 (1975).

41. Bradley v. School Bd. of the City of Richmond, 462 F.2d 1058, 1066 (4th Cir. 1972).

42. 418 U.S. 717 (1974). 
alike. Likewise, there are a variety of alternative educational philosophies and practices which are being employed as responses to the realities of desegregation. But amid these contingencies and multiple sets of assumptions as to what is to be done, there remains the imperative of a better understanding of the social and educational processes of desegregation. As we believe is apparent from this present volume, there are some dimensions of the issue where we can speak with some certainty and confidence, but there remain others where we have barely begun to understand the complexities and nuances involved. 